\title{
Development and Quality Evaluation of Dahi Fortified with Beta Carotene Rich Sweet Potato Juice Variety Bhu-Sona
}

\author{
Venkatraman Bansode $^{1 *}$, Vijay Bahadur Singh Chauhan ${ }^{1}$, Kalidas Pati ${ }^{1}$, \\ Namrata Giri ${ }^{2}$, T. Krishnakumar ${ }^{2}$, Kiran Bhuyar ${ }^{3}$, Pradeepika Chinta ${ }^{2}$, M. \\ Nedunchezhiyan $^{1}$ and M.S. Sajeev ${ }^{2}$ \\ ${ }^{1}$ ICAR-Central tuber Crops Research Institute, Regional Centre, \\ Dumduma H.B., Bhuaneswar-751019 (Odisha), India \\ ${ }^{2}$ ICAR-Central tuber Crops Research Institute, Sreekariyam, \\ Trivandrum-695017 (Kerala), India \\ ${ }^{3}$ Priyadarshani Institute of Engineering and Technology, RTMNU, \\ Nagpur-440009 (M.S), India
}

*Corresponding author

\section{A B S T R A C T}

\section{Keywords}

$\beta$-carotene, dahi, sweet potato juice,

Nutritional composition, Physical characteristics, Sensory evaluation

Article Info

Accepted:

07 June 2019 Available Online: 10 July 2019
The research was conducted to prepare $\beta$-carotene rich dahi with different levels of sweet potato (SP) juice $(10,20,30,40$ and 50\%). Different physical, nutritional and sensory characteristics were analysed to assay the quality of $\beta$-carotene rich dahi. Data on different parameters were recorded and analyzed. It was found that the physical, nutritional and sensory qualities of dahi improved by addition of Sweet potato juice. Addition of SP juice increases the Protein (3.60 to $6.77 \mathrm{~g})$, Ash $(0.71$ to $3.79 \%$ ) and $\beta$ carotene content $(4.52 \mathrm{mg} / 100 \mathrm{~g})$. It also revealed that $30 \%$ Sweet potato juice addition shown superior results for Flavour, Texture, Colour as well as Overall acceptability. Enriching Dahi with $\beta$-carotene rich sweet potato juice will boost as a functional food. The finding of this research may give an overall idea about manufacturing of $\beta$-carotene rich dahi and appropriate technology of $\beta$-carotene rich dahi preparation.

\section{Introduction}

Sweet potato (Ipomea batatas L. Lam) is an important root crop grown in many tropical countries. Human consumption is one of the most important uses of sweet potatoes in both temperate and tropical growing areas and they are used either fresh or processed products. In India, the roots of this crop are consumed either as fresh vegetable or as boiled or baked products in the diet of rural and tribal people (Ray and Balagopalan, 1997). These roots are rich in starch, vitamins and minerals (Woolfe, 1992). Some sweet potato varieties contain 
coloured pigments-anthocyanin, $\beta$-carotene and an unidentified flavonoid. These pigments are regarded as beneficial antioxidation, anticancer and protection against liver injury (Yamakawa, 2000).

Sweet potato is expected to play a vital role in combating the food shortages and malnutrition that may increasingly occur as a result of population growth and pressure on land utilization (Naskar et al., 2008).

Orange fleshed sweet potato (variety $B h u$ sona) is one of the cheapest sources of $\beta$ carotene. Vitamin A is build-up by human body when it has adequate amount of its precursor $\beta$-carotene. Vitamin A deficiency is a public health problem in more than half of all countries, especially in Africa and SouthEast Asia hitting hardest young children and pregnant women in low income countries.

Dahi (Indian yoghurt), the products of lactic acid fermentation of milk are reported to possess several nutritional/dietary advantages over milk. The yoghurt is popular in Europe and American countries; consumption of dahi is very common among Asian people, especially in Indian sub-continent.

There are different forms of dahi such as sweet dahi, sour dahi and flavoured dahi which are customarily consumed by the people of all over the world.

Consumption of Dahi is linked with several health benefits because of their presence of lactic acid bacteria. In dahi much of the lactose in milk is converted to digestible lactic acid and serves as valuable source of protein, essential vitamins and minerals. Hence the present study was designed to manufacture $\beta$ carotene rich dahi fortified with different levels of sweet potato juice with whole milk and to compare qualities on the basis of physical, chemical and microbial parameters.

\section{Materials and Methods}

The freshly harvested sweet potato tubers of variety Bhu-sona was collected from the experimental farm of the Regional centre of ICAR-Central Tuber Crops Research Institute, Bhubaneswar, Odisha.

\section{Preparation of starter culture}

Half litre of cow milk (Source: Orissa Milk Federation, OMFED, Orissa) was taken and pasteurized at $80-90^{\circ} \mathrm{C}$ for about $10-15$ minutes. Then it was cooled at room temperature, $30 \pm 2{ }^{\circ} \mathrm{C}$. After cooling, $5 \mathrm{ml}$ of previously prepared homemade dahi was inoculated into the milk. The whole mixture was kept in an incubator at $30{ }^{\circ} \mathrm{C}$ for $12 \mathrm{~h}$ to prepare dahi starter culture.

\section{Preparation of sweet potato juice}

$200 \mathrm{gm}$ of the sweet potato variety Bhu-sona was weighed and washed properly to ward off the dirt. Then it was peeled off and was cut into cubes. Then the cubes were boiled for 15 minutes till they become tender. Then the whole mixture was allowed to cool down. After cooling, it was transferred into a grinder to make juice out of it. For each $200 \mathrm{gm}$ of sample, $200 \mathrm{ml}$ of water was used into order to make juice. After that, the juice was filtered using a muslin cloth and the extracted juice was used further in the experiment.

Preparation of plain dahi (Control) and $\beta$ carotene rich (fortified with sweet potato juice) dahi

Whole milk was pasteurized and heated to reduce about one third of its original volume. During heating milk was stirred continuously with the help of stirrer to avoid the formation of cream layer. After desired heating milk pan was taken out from heater and allowed to cool. The sweet potato juice which is previously 
pasteurized was incorporated into Dahi at 10, 20, 30, 40 and 50\% level in different cups except control (Hossain et.al, 2012). Sweet potato juice was added before incubation with starter culture $(2 \%)$. The plastic cups were pre-washed with boiled water before use. The samples were incubated at $37{ }^{\circ} \mathrm{C}$ until the complete dahi formation (8-12 h). The dahi samples were stored at about $4{ }^{\circ} \mathrm{C}$ at refrigeration until used.

\section{Physic-chemical analyses of $\beta$-carotene rich Sweet Potato Dahi}

Data were collected for several physicchemical (moisture, $\mathrm{pH}$, protein, ash, $\beta$ carotene content, titratable acidity (TA) and lactic acid (LA) parameters, by following the standard procedures mentioned by Amerine and Ough (1980).

\section{Sensory evaluation}

The prepared $\beta$-carotene rich sweet potato dahi was subjected for sensory evaluation. Ten individuals served as panellists, were trained to evaluate dahi as per score card (Scale 1-5) developed by committee of American Dairy Science Association (USDA, 1984) to evaluate dairy product for flavour, texture, colour and acceptability (Bodyfelt et al., 1988).

\section{Results and Discussion}

\section{Physical characteristics of $\beta$-carotene rich sweet potato (SP) dahi}

The changes in $\mathrm{pH}$, Titrable acidity and Lactic acid content of sweet potato dahi depicted in Table 1. The $\mathrm{pH}$ is a critical factor in developing satisfactory flavour and consistency of dahi. The optimum $\mathrm{pH}$ of milkbased product like yoghurt is reported to be at 4.0-4.5 (Varnam and Sutherland, 1994). In our investigation, the $\mathrm{pH}$ ranges from 3.98
(Control sample)-4.20 ( $\left.\mathrm{T}_{5}\right)$. As concentration of sweet potato (SP) \% in dahi increased the $\mathrm{pH}$ of sample get increased. It might be due to addition of sweet potato juice in dahi samples.

Titrable acidity (TA) measured in terms of $\mathrm{g}$ LA. $100 \mathrm{~g}^{-1}$ of sweet potato dahi did not show significant variations irrespective of the concentration of sweet potato juice. Similarly, Lactic acid of sweet potato dahi varied from 0.60 to 0.72 . However, it is reported that percentage of titrable acidity decreased with increased levels of sweet potato, sugars and fermentation time in case of preparation of sweet potato yoghurt (Collins et al., 1991).

\section{Proximate composition of $\beta$-carotene rich sweet potato (SP) dahi}

As the amount of sweet potato increased in preparation of dahi, the moisture content decreased. The amount (dry weight basis) of this component was affected because sweet potato contained higher amount of solids than milk. The similar results were found by Ray et al., 2005. The protein and ash content varies from $3.60 \mathrm{~g}$ to $6.67 \mathrm{~g}$ and $0.71 \%$ to $3.79 \%$ respectively. The slight increase in protein and ash content might be due to increased level of sweet potato percentage in the product.

The $\beta$-carotene contents of sweet potato dahi were expressed as $\mathrm{mg} .100 \mathrm{~g}^{-1}$. With increase in sweet potato concentration in dahi, the concentration of $\beta$-carotene in sweet potato dahi increased proportionally.

The similar results are good agreement with Venkatraman et al., 2018. The $\beta$-carotene is considered to be precursor of Vitamin A; this attribute has an additive beneficial impact on sweet potato dahi. The fat and total solids ranged from $4.12 \mathrm{~g}$ to $4.52 \mathrm{~g}$ and $25.31 \%$ to $25.69 \%$ respectively. The fat content in the dahi samples were slightly decreased from $\mathrm{T}_{1}$ to $\mathrm{T}_{5}$ samples (Table 2). 
Table.1 Physical characteristics of $\beta$-carotene rich sweet potato (SP) dahi

\begin{tabular}{|l|l|l|l|}
\hline $\begin{array}{l}\text { S.P (\%) in } \\
\text { dahi }\end{array}$ & $\mathbf{p H}$ & $\begin{array}{l}\text { Titrable acidity } \\
\text { (g/100 g dahi) }\end{array}$ & $\begin{array}{l}\text { Lactic acid } \\
\text { (g/100 g dahi) }\end{array}$ \\
\hline Control & $3.98 \pm 0.068$ & $1.21 \pm 0.024$ & $0.72 \pm 0.035$ \\
\hline $\mathbf{T}_{\mathbf{1}}$ & $4.03 \pm 0.038$ & $1.35 \pm 0.029$ & $0.69 \pm 0.016$ \\
\hline $\mathbf{T}_{\mathbf{2}}$ & $4.05 \pm 0.066$ & $1.31 \pm 0.057$ & $0.66 \pm 0.033$ \\
\hline $\mathbf{T}_{\mathbf{3}}$ & $4.09 \pm 0.073$ & $1.28 \pm 0.012$ & $0.63 \pm 0.012$ \\
\hline $\mathbf{T}_{\mathbf{4}}$ & $4.12 \pm 0.032$ & $1.23 \pm 0.020$ & $0.62 \pm 0.028$ \\
\hline $\mathbf{T}_{\mathbf{5}}$ & $4.20 \pm 0.032$ & $1.22 \pm 0.028$ & $0.60 \pm 0.036$ \\
\hline
\end{tabular}

\pm Standard deviation

Table.2 Proximate composition of $\beta$-carotene rich sweet potato (SP) dahi

\begin{tabular}{|l|l|l|l|l|l|l|}
\hline $\begin{array}{l}\text { S.P (\%) } \\
\text { in dahi }\end{array}$ & \multicolumn{7}{|c|}{ Parameters } \\
\cline { 2 - 7 } & $\begin{array}{l}\text { Moisture } \\
(\%)\end{array}$ & $\begin{array}{l}\text { Protein } \\
(\mathrm{g})\end{array}$ & $\begin{array}{l}\text { Ash } \\
(\%)\end{array}$ & $\begin{array}{l}\beta \text {-carotene } \\
(\mathrm{mg} / 100 \mathrm{gm})\end{array}$ & $\begin{array}{l}\text { Fat } \\
(\mathrm{g})\end{array}$ & $\begin{array}{l}\text { Total solids } \\
(\%)\end{array}$ \\
\hline Control & $74.05 \pm 0.020$ & $3.60 \pm 0.029$ & $0.71 \pm 0.012$ & Nil & $4.52 \pm 0.029$ & $25.49 \pm 0.029$ \\
\hline $\mathbf{T}_{\mathbf{1}}$ & $75.74 \pm 0.098$ & $5.22 \pm 0.041$ & $3.21 \pm 0.024$ & $1.82 \pm 0.050$ & $4.27 \pm 0.061$ & $25.31 \pm 0.038$ \\
\hline $\mathbf{T}_{\mathbf{2}}$ & $75.02 \pm 0.054$ & $5.82 \pm 0.041$ & $3.41 \pm 0.024$ & $2.56 \pm 0.049$ & $4.21 \pm 0.043$ & $25.45 \pm 0.063$ \\
\hline $\mathbf{T}_{\mathbf{3}}$ & $74.22 \pm 0.021$ & $5.98 \pm 0.026$ & $3.54 \pm 0.020$ & $3.21 \pm 0.024$ & $4.16 \pm 0.024$ & $25.47 \pm 0.035$ \\
\hline $\mathbf{T}_{\mathbf{4}}$ & $73.10 \pm 0.053$ & $6.14 \pm 0.024$ & $3.67 \pm 0.038$ & $3.85 \pm 0.032$ & $4.13 \pm 0.032$ & $25.69 \pm 0.069$ \\
\hline $\mathbf{T}_{\mathbf{5}}$ & $73.03 \pm 0.024$ & $6.77 \pm 0.040$ & $3.79 \pm 0.032$ & $4.52 \pm 0.028$ & $4.12 \pm 0.028$ & $25.48 \pm 0.035$ \\
\hline
\end{tabular}

\pm Standard deviation

Table.3 Sensory scores (Scale of 1-5) of $\beta$-carotene rich sweet potato (SP) dahi

\begin{tabular}{|l|l|l|l|l|}
\hline \multirow{2}{*}{$\begin{array}{l}\text { S.P (\%) in } \\
\text { dahi }\end{array}$} & \multicolumn{4}{|c|}{ Attributes } \\
\cline { 2 - 5 } & Flavour & Texture & Colour & Acceptability \\
\hline Control & $2.63 \pm 0.024$ & $3.67 \pm 0.032$ & $2.88 \pm 0.024$ & $3.27 \pm 0.021$ \\
\hline T1 & $2.18 \pm 0.016$ & $2.11 \pm 0.024$ & $3.14 \pm 0.028$ & $2.95 \pm 0.020$ \\
\hline T2 & $3.12 \pm 0.016$ & $3.70 \pm 0.038$ & $3.14 \pm 0.020$ & $3.45 \pm 0.049$ \\
\hline T3 & $4.21 \pm 0.065$ & $3.77 \pm 0.020$ & $3.22 \pm 0.016$ & $3.63 \pm 0.024$ \\
\hline T4 & $3.00 \pm 0.041$ & $2.87 \pm 0.030$ & $2.74 \pm 0.037$ & $3.20 \pm 0.032$ \\
\hline T5 & $2.15 \pm 0.012$ & $2.13 \pm 0.032$ & $2.05 \pm 0.033$ & $2.55 \pm 0.041$ \\
\hline
\end{tabular}

\pm Standard deviation

Sensory evaluation of $\beta$-carotene rich sweet potato (SP) dahi

Ten member consumer panel evaluated the dahi samples consisting of $10 \%$ to $50 \%$ of sweet potato-milk mixture (Table 3). The panel used the score card developed by a committee of American Dairy Science
Association (USDA, 1984) to evaluate flavour, colour, appearance etc. In our study, four attributes (flavour, texture, colour and acceptability) were selected to evaluate sweet potato dahi. A mean score of 4.21 (scale of 15 ) indicated flavour was rated relatively high. The mean score of 3.9 for texture and 3.22 score for colour indicated sweet potato to 
produce favourable effects. Similarly, a mean score of 3.63 was attributed for acceptability of sweet potato dahi. However, the consumer panel preferred the colour, flavour, texture and acceptability of the sweet potato dahi with 20 and $30 \%$ sweet potato juice that scored $>3$ (scale 1-5).

In conclusion, sweet potato dahi was prepared by fermenting a mixture of milk and $\beta$ carotene rich sweet potato (variety Bhu-Sona) juice. Sweet potato provided minerals, $\beta$ carotene and protein, which also functioned as a thickener and stabilizer. There was no any measure constraint in preparing sweet potato dahi unlike bean curd or soya curd. Moreover, dahi is a regular component of daily diet of many people in Indian Sub-continent. Enriching dahi with $\beta$-carotene rich sweet potato will boost the former as a functional food.

\section{References}

Amerine MA and Ough C 1980. Methods for Analysis of Musts and Wines. Wiley Interscience Publication, John Wiley and Sons, New York.

Bodyfelt FW, Tobias, J and Trout, G 1988. The sensory Evaluation of Dairy products. Van No Strand Reinhold Publishers, New York.

Collins JL, Bah CB, Mount JR, Dravghon FA and Demott BJ 1991. Proximate, nutritional and microbiological analysis of milk sweet potato mixtures fermented with yoghurt bacteria. J.Food Sci.56: 682-684.

Hossain MN, Fakruddin M and Nurul I 2012. Development of Fruit Dahi (yoghurt) fortified with Strawberry, Orange and Grape Juice. American Journal of Food Technology, 7(9) 562-570.

Ray RC and Balagopalan C 1997. Postharvest spoilage of sweet potato, Central Tuber Crops Research Institute, Tech. Bull No.17, Trivandrum, 29 pp.

USDA 1984. Composition of Foods: Vegetables and Vegetable products Raw, Processed and prepared. Agricultural Hand Book, U.S. Department of Agriculture, Washington, D.C.

Venkatraman Bansode, Shovna Smruti, Vijay Bahadur Singh Chauhan, Sudhansu Shekhar Mahanand and Archana Mukherjee 2018. Effect of Initial pH, Chemical Preservatives and Storage Temperature on the Shelf-life of $\beta$ Carotene Rich Sweet Potato Dahi. Int.J.Curr.Microbiol.App.Sci. $\quad$ 7(08): 960-968.

Woolfe JA 1992. Sweet potato an Untapped Food Resource. Cambridge University Press, Cambridge, England, 643 pp.

Yamakawa, O. 2000. Development of new cultivation and utilization system for sweet potato towards the $21^{\text {st }}$ century. In: Proc. Intern Workshop on sweet potato: Production system towards $21^{\text {st }}$ century, Miyakonojo, Miyazaki, Japan, pp. 1-8.

\section{How to cite this article:}

Venkatraman Bansode, Vijay Bahadur Singh Chauhan, Kalidas Pati, Namrata Giri, T. Krishnakumar, Kiran Bhuyar, Pradeepika Chinta, M. Nedunchezhiyan and Sajeev, M.S. 2019. Development and Quality Evaluation of Dahi Fortified with Beta Carotene Rich Sweet Potato Juice Variety Bhu-Sona. Int.J.Curr.Microbiol.App.Sci. 8(07): 575-579. doi: https://doi.org/10.20546/ijcmas.2019.807.071 